\section{Comparison of Reproductive \\ Performance of the Roe Deer (Capreolus capreolus, L.) Among Different Regions}

\author{
István Majzinger \\ University of Szeged, \\ College of Agriculture,
}

Institute of Animal Sciences and Wildlife Management, Hódmezővásárhely

mi@mfk.u-szeged.hu

\section{SUMMARY}

The potential and actual number of offspring of roe deer and the difference between these figures (prenatal and postnatal loss) significantly vary in each population yearly. The objective of this study is to examine the potential and actual number of offspring, the number of losses, and to find a link between the most important biological characteristics of does (body weight - BW, condition KFI) and the number of raised offspring on four territories on the Great Hungarian Plain.

Where the number of corpora lutea (CL) is the highest, there the losses are the highest as well, and the number of raised offspring is the lowest (region I.). Here, the rearing loss is double that of the weakest territory (region IV.). Rearing losses can be associated with the fenotype of does (BW, KFI) but environmental factors also have determinative importance. Where the number of twin-calving does was the highest, I found four times more does without a fawn than where the number of twin-calving does was the lowest. The nursing success was the best (the losses were lowest) in the region where the potential offspring (number of $C L$ ) was also the lowest, but the coverage of the habitat and the proportion of forests were largest. The food supply for the animals in autumn and winter are not enough, the structure of the habitat has to be improved as well, so that it might become adequate for game protection in extreme weather conditions.

The results have to be considered as preliminary ones. It is essential to continue and extend the research to increase the reliability of the results.

Keywords: reproduction, roe deer, corpus luteum, sex-ratio, fertility, post natal loss, raised offspring, kidney fat index, body weight

\section{INTRODUCTION}

The reproductive performance of roe deer (Capreolus capreolus, L.) shows significant differences by territory, by year and by stock. Prenatal and postnatal losses basically determine the difference between potential and actual (raised) offspring. Postnatal losses are the higher, and these occur in the summer period after the birth of the fawns. The survival of the fawns in summer is rather uncertain and shows great variance: in Denmark 0.20.78 (Strandgaard, 1972), in England 0.28-1 (Gill, 1994 cit. Andersen et al., 1998), in Germany 0.570.93 (Thor, 1995), in France 0.38-0.84, and 0.44-0.92 (Gaillard et al., 1997). König (1988) found an upbringing rate of 0.74 fawn/doe at the end of August in Hungary. He believes that one half of the high fawn losses occurs during the first three months of their life.

My objective is to examine the number of potential and actual offspring, as well as the number of losses, in certain territories. I also wish to find a link between the most important biological characteristics of does (body-weight, condition) and the number of offspring. This method can be used in planning the harvest of roe stocks.

\section{MATERIAL AND METHOD}

While each of the examined regions has a significant roe deer stocks, their quality is different, mainly because of their different habitats. The examined regions are the following:

- Intensive cultivation agricultural area (I.) in Békés county: forest $1 \%$, meadows and pastures $5 \%$, soil $83 \%$, other $11 \%$. The roe deer stock's quality is excellent (declared in the Game Management District Plan).

- Agricultural area and lowland (II.) in Csongrád county: forest $1 \%$, meadows and pastures $17 \%$, soil $75 \%$, other $7 \%$. The roe deer stock's quality is good.

- Intensive cultivation agricultural area (III.) in Csongrád county: forest $1 \%$, meadows and pastures $7 \%$, soil $74 \%$, other $18 \%$. The roe deer stock's quality is good.

- Sandy soil agricultural area and woodland (IV.) in Csongrád county: forest 27\%, meadows and pastures $19 \%$, soil $39 \%$, vineyard and orchard $12 \%$, other $3 \%$. The roe deer stock's quality is medium.

I determined the number of corpora lutea $(\mathrm{CL})$ by examining the ovary, the body weight (BW) with the head and the legs but without the viscera, and the kidney fat index (KFI - using method of Caughley and Sinclair, 1994). The survey contains data on 271 does shot in the 2002-2003 and 2003-2004 hunting seasons.

Together with the gamekeepers, we observed and counted the animals with the help of binoculars and spectives. I observed 555 roe deer in order to estimate the number of raised offspring in OctoberNovember 2003. At that time, the vegetation cover was not significant, so visibility was good. It had not formed Large-number groups by then, so we were able to observe fawn association to the mother with greater accuracy. To assess the number of raised 
offspring in the autumn population, we had to estimate the number of fertile does that had not yet calved. As these animals cannot be differentiated by phenotype at this age (1.5-years-old), I determined the rate of the yearling by my own calculation method from the reported national data (Table 1):

$$
Y D(\%)=\frac{\left(1-M_{F}\right) * 0,5 F_{S}}{\left(1-M_{F}\right) * 0,5 F_{S}+\left(1-M_{D}\right) * D_{S}} * 100
$$

- YD (\%): proportion of yearling does (probably pregnant but not yet parturited) within the mature female stock at the beginning of the hunting season ( $1^{\text {st }}$ October).

- $\mathrm{M}_{\mathrm{F}}$ : mortality rate of fawns.

- $\mathrm{F}_{\mathrm{S}}$ : total number of fawns in spring stock.

- $\mathrm{M}_{\mathrm{D}}$ : mortality rate of does.

- $\mathrm{D}_{\mathrm{S}}$ : total number of does in spring stock.
- $\left(1-\mathrm{M}_{\mathrm{F}}\right)^{*} 0,5 \mathrm{~F}_{\mathrm{S}}$ : part of survived female fawns counted in spring within the autumn stock $\left(1^{\text {st }}\right.$ October).

- $\left(1-\mathrm{M}_{\mathrm{D}}\right) * \mathrm{D}_{\mathrm{S}}$ : part of survived does counted in spring within the autumn stock ( $1^{\text {st }}$ October).

- $\left(1-\mathrm{M}_{\mathrm{F}}\right) * 0,5 \mathrm{~F}_{\mathrm{S}}+\left(1-\mathrm{M}_{\mathrm{D}}\right) * \mathrm{D}_{\mathrm{S}}$ : total number of does in autumn ( $1^{\text {st }}$ October).

The calculation of the rate of the young does (yearling) was carried out by different survival parameters, and it can be seen in Table 1 that despite the significant losses due to mortality, the composition of the doe population - the rate of young does - does not differ significantly from $25 \%$. This is why I used this ratio when calculating the number of raised offspring on the examined territories, presuming that there is not any significant difference between the national average and the examined territories concerning the stock composition of does.

Data processing was done using SPSS for Windows programme.

Estimated proportion of yearling females (probably pregnant but not yet parturited) within the female stock in autumn

\begin{tabular}{|c|c|c|c|c|c|}
\hline Year & $\mathbf{D}_{\mathrm{s}}{ }^{+}$ & $\mathbf{F}_{\mathrm{S}}{ }^{+}$ & YD (\%)* & YD (\%)** & YD $(\%)^{* * *}$ \\
\hline 1985 & 92901 & 55229 & 22,3 & 21,9 & 21,0 \\
\hline 1986 & 93690 & 56578 & 22,6 & 22,2 & 21,3 \\
\hline 1987 & 90150 & 58164 & 23,8 & 23,4 & 22,4 \\
\hline 1988 & 88501 & 54837 & 23,1 & 22,7 & 21,7 \\
\hline 1989 & 92986 & 55629 & 22,5 & 22,1 & 21,1 \\
\hline 1990 & 96975 & 62559 & 23,8 & 23,4 & 22,4 \\
\hline 2000 & 115995 & 75648 & 24,0 & 23,6 & 22,6 \\
\hline 2001 & 120891 & 81938 & 24,7 & 24,3 & 23,3 \\
\hline 2002 & 124094 & 86016 & 25,1 & 24,7 & 23,7 \\
\hline 2003 & 126084 & 90450 & 25,8 & 25,4 & 24,3 \\
\hline
\end{tabular}

${ }^{+}$: total Country data

*: in favourable year, when mortality rate of fawns $\left(\mathrm{M}_{\mathrm{F}}\right)=5 \%$, mortality rate of does $\left(\mathrm{M}_{\mathrm{D}}\right)=2 \%$

**: in average year, when mortality rate of fawns $\left(\mathrm{M}_{\mathrm{F}}\right)=10 \%$, mortality rate of does $\left(\mathrm{M}_{\mathrm{D}}\right)=5 \%$

$* * *$ : in unfavourable year, when mortality rate of fawns $\left(\mathrm{M}_{\mathrm{F}}\right)=15 \%$, mortality rate of does $\left(\mathrm{M}_{\mathrm{D}}\right)=5 \%$

\section{RESULTS}

\section{Structure of stocks and reproductive parameters}

Table 2 shows that stock compositions differ by region, the sex-ratio of the grown-ups shows 1:1.21.9. The reason for this is the regulation originated from the territorial behaviour of bucks and also the under-harvesting of the does. We also have to take into consideration the fact that significant doe harvest was still to be completed, e.g. in Region III, during the examination period. The 1:2.7 sex-ratio registered in Region IV cannot be regarded as reliable because of the reason indicated in the table 2. All in all, the sex-ratio of the fawns (where any estimation was possible) has shifted towards the female sex. In Region I, the sex ratio of the fawns does not differ significantly from 1:1. The reproduction index shows great differences between the regions concerning the number of CL, the number of the raised offspring, breeding losses or the rate of does without fawns. There is a $18 \%$ difference in CL number, a $39 \%$ difference in average raised offspring, and a more than $250 \%$ difference in the ratio of does without fawns.

Fertility is $100 \%$ in all regions, which means that all harvested does had a CL, as all were in oestrous (Table 3). This does not mean pregnancy in every case, as the regression of the CL occurs only in January when the female did not get pregnant, or when implantation did not occur previously.

The average number of CL (potential offspring) shows significant variation between the regions (Table 4).

A higher number of CL, however, does not guarantee a higher number of raised offspring. In regions with the highest $\mathrm{CL}$ numbers, the losses are also the highest and the number of raised offspring is the lowest (Figure 1). 
Summarized data of animal counting, stock composition and reproductive values of does

\begin{tabular}{|c|c|c|c|c|c|c|}
\hline & Observed roe deers & Region I. & Region II. & Region III. & Region IV. & Total \\
\hline 1. & Buck (yearling+mature) & 94 & 38 & 16 & 15 & 163 \\
\hline 2. & Doe (yearling+mature) & 112 & 43 & 28 & 40 & 223 \\
\hline 3. & Total $(1+2)$ & 206 & 81 & 44 & 55 & 386 \\
\hline 4. & Male fawn & 25 & - & - & 4 & 29 \\
\hline 5. & Female fawn & 28 & - & - & 16 & 44 \\
\hline 6. & Fawn of unknown gender & 15 & 37 & 27 & 17 & 96 \\
\hline 7. & Total fawns $(4+5+6)$ & 68 & 37 & 27 & 37 & 169 \\
\hline 8. & Total roes $(3+7)$ & 274 & 118 & 71 & 92 & 555 \\
\hline 9. & Total does (corrected)**(100\%) & 120 & 45 & 30 & 40 & 235 \\
\hline 10. & Yearling (not parturited) in it $(25 \%)^{*}$ & 30 & 11 & 7 & 10 & 58 \\
\hline 11. & Mature doe in it (75\%) & 90 & 34 & 23 & 30 & 177 \\
\hline 12. & Adult sex ratio (1/9) & $1: 1,3$ & $1: 1,2$ & $1: 1,9$ & $1: 2,7 * * *$ & $1: 1,4$ \\
\hline 13. & Average grown up offspring per doe $(7 / 11)$ & 0,75 & 1,09 & 1,17 & 1,23 & 0,95 \\
\hline 14. & Average number of CL per doe & 2,10 & 2,13 & 1,84 & 1,75 & 2,02 \\
\hline 15. & Average pre- and postnatal losses per doe (14-13) & 1,35 & 1,04 & 0,67 & 0,52 & 1,07 \\
\hline 16. & Losses $(\%)$ & 64,2 & 48,8 & 36,4 & 29,7 & 52,9 \\
\hline 17. & Number of does that are without fawns & 61 & 19 & 11 & 14 & 105 \\
\hline 18. & Mature does in it $(17-10)$ & 31 & 8 & 4 & 4 & 47 \\
\hline 19. & Proportion of mature does without fawns (\%) (18/11) & 34,4 & 23,5 & 17,4 & 13,3 & 26,5 \\
\hline
\end{tabular}

Descriptive Statistics of CL number and fertility in female roe deer in the 2002 hunting year

\begin{tabular}{|c|c|c|c|c|}
\hline Region & Mean & Std. Deviation & $\mathbf{N}$ & $\begin{array}{c}\text { Fertility } \\
\%\end{array}$ \\
\hline I. & 2,10 & ,307 & 39 & 100 \\
\hline II. & 2,13 & ,351 & 22 & 100 \\
\hline III. & 1,84 &, 376 & 13 & 100 \\
\hline IV. & 1,75 &, 452 & 12 & 100 \\
\hline
\end{tabular}

Multiple comparisons of $\mathrm{Cl}$ number between the regions in the 2002 hunting year

\begin{tabular}{|c|c|c|c|c|}
\hline $\begin{array}{c}\text { (I) } \\
\text { Region }\end{array}$ & $\begin{array}{c}\text { (J) } \\
\text { Region }\end{array}$ & $\begin{array}{c}\text { Mean Difference } \\
\text { (I-J) }\end{array}$ & Std. Error & Sig. \\
\hline \multirow{3}{*}{ I. } & II. &,- 03 & ,094 &, 719 \\
\hline & III. & ,26** &, 113 &, 025 \\
\hline & IV. & ,35* &, 116 &, 003 \\
\hline \multirow{3}{*}{ II. } & I. &, 03 & ,094 &, 719 \\
\hline & III. & ,29** &, 123 & ,021 \\
\hline & IV. &, $39 *$ & , 126 &, 003 \\
\hline \multirow{3}{*}{ III. } & I. &,$- 26 * *$ &, 113 &, 025 \\
\hline & II. &,$- 29 * *$ &, 123 & 021 \\
\hline & IV. &, 10 &, 141 & 4,496 \\
\hline \multirow{3}{*}{ IV. } & I. &,$- 35^{*}$ &, 116 &, 003 \\
\hline & II. &,$- 39 *$ & , 126 & ,003 \\
\hline & III. &,- 10 & , 141 & 496 \\
\hline
\end{tabular}

\footnotetext{
*: The mean difference is significant at the, 01 level (ANOVA)
}

**: The mean difference is significant at the, 05 level (ANOVA) 
Figure 1: Variation of raised offspring (fawn) per doe in relation to pre- and postnatal losses

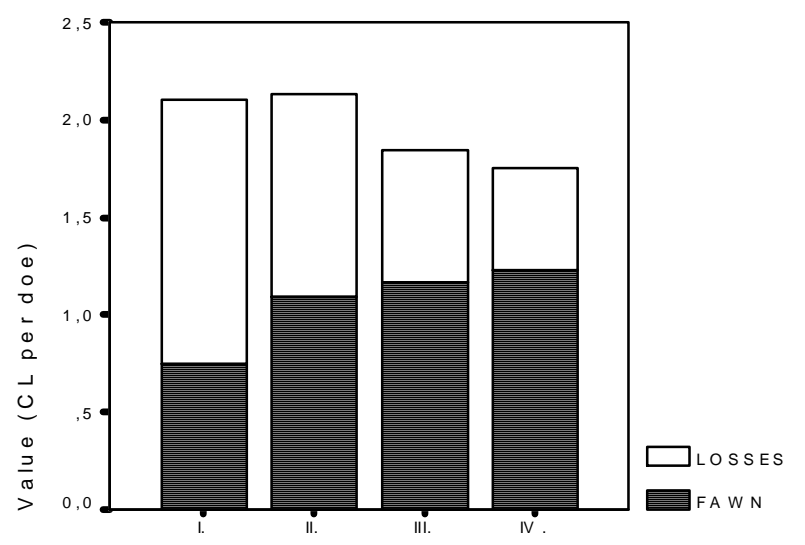

The CL distribution can be determined safely from the harvested does, and also the association of fawns to their mothers (at the time of the observation). Consequently, we can examine the distribution of the raised offspring - with approximate accuracy - in each region (Table 5). In this way, we can see which groups of does suffered the greatest losses (Figure 2).

Where the number of raised offspring is the lowest, the number of does without fawns is the highest and the number of does with one or two fawns is the lowest too. In Region I the potential number of offspring is 2.1 per doe and the average fawn number is only 0.75 . Here the ratio of does without fawns is twice as great $(34 \%)$ as that of Region IV (13\%), where, in addition to the lowest potential offspring number (1.75), the number of raised offspring is the highest (1.23) (Figure 2).

Distribution of potential (number of CL) * and realised (raised) ** offspring

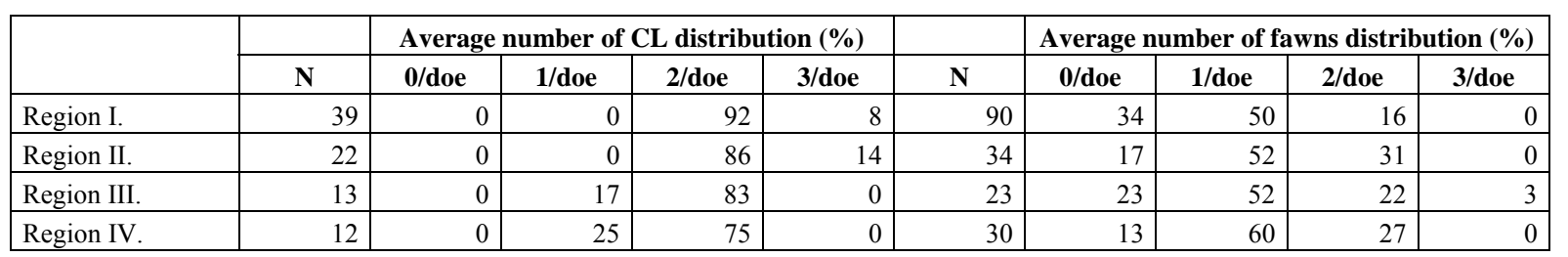

$*$ : in the 2002 hunting year

**: in October-November of $2003^{\text {th }}$

Figure 2: Distribution of raised offspring per doe in relation to average figures

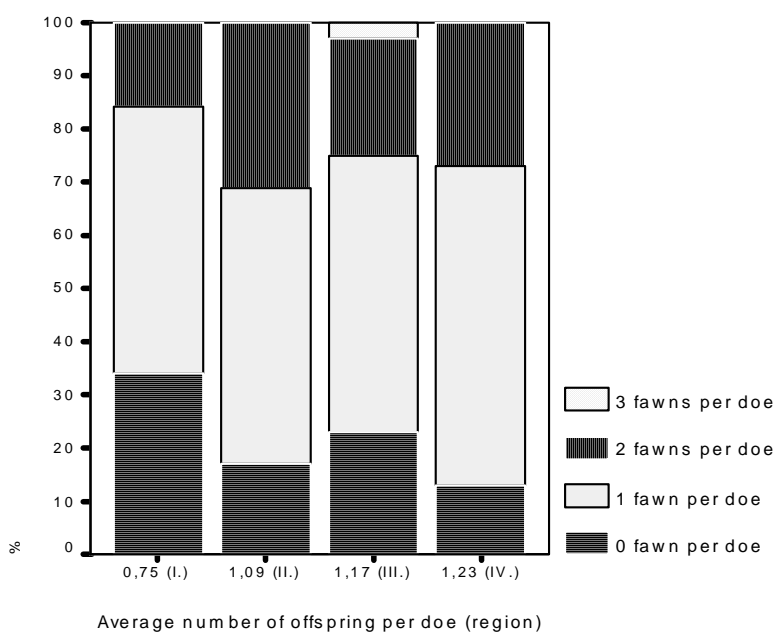

The connection between body weight, kidney fat index and reproductive parameters

It is well-known that the BW and the condition of the does affect reproductive performance. Does have to reach a minimum threshold of BW before the first oestrus, furthermore, the BW effects the number of CL (the number of the potential offspring, primary natality) of the mating does (Hewison and Gaillard, 2001).

Where the average number of CL is high the average number of raised offspring is low (Figure 3, Table 6).

Since presumably all ovulated ovums are fertilised and their number is approximately the same as the number of $\mathrm{CL}$, we can consider them as potential offspring and the higher their number is, the higher the BW of the does is (Figure 4, Table 6).

Basic data of does according to region

\begin{tabular}{|c|c|c|c|c|c|c|c|c|c|c|}
\hline \multirow[t]{2}{*}{ Region } & \multicolumn{3}{|c|}{$\begin{array}{c}\mathrm{BW}^{*}, \mathrm{~kg} \\
(2002)\end{array}$} & \multicolumn{2}{|c|}{$\begin{array}{c}\text { Number of CL } \\
(2002)\end{array}$} & \multicolumn{3}{|c|}{$\begin{array}{c}\text { KFI } \\
(2003)\end{array}$} & \multicolumn{2}{|c|}{$\begin{array}{c}\text { Raised offspring } \\
(2003)\end{array}$} \\
\hline & $\mathbf{N}$ & $\bar{x}$ & $S_{x}$ & $\mathbf{N}$ & $\bar{x}$ & $\mathbf{N}$ & $\bar{x}$ & $\mathrm{~S}_{\mathrm{x}}$ & $\mathbf{N}$ & $\bar{x}$ \\
\hline I. & 39 & 18,40 & $\pm 0,64$ & 39 & 2,10 & 106 & 0,97 & $\pm 0,94$ & 90 & 0,75 \\
\hline II. & 22 & 18,61 & $\pm 0,69$ & 22 & 2,13 & 23 & 0,89 & $\pm 0,86$ & 34 & 1,09 \\
\hline III. & 13 & 16,31 & $\pm 1,37$ & 13 & 1,85 & 48 & 1,04 & $\pm 1,00$ & 23 & 1,17 \\
\hline IV. & 12 & 17,92 & $\pm 0,99$ & 12 & 1,75 & 8 & 1,38 & $\pm 0,65$ & 30 & 1,23 \\
\hline
\end{tabular}

*: eviscerated body without head and legs 
Figure 3: The raised offspring and the average number of $\mathrm{CL}$ in the examined regions

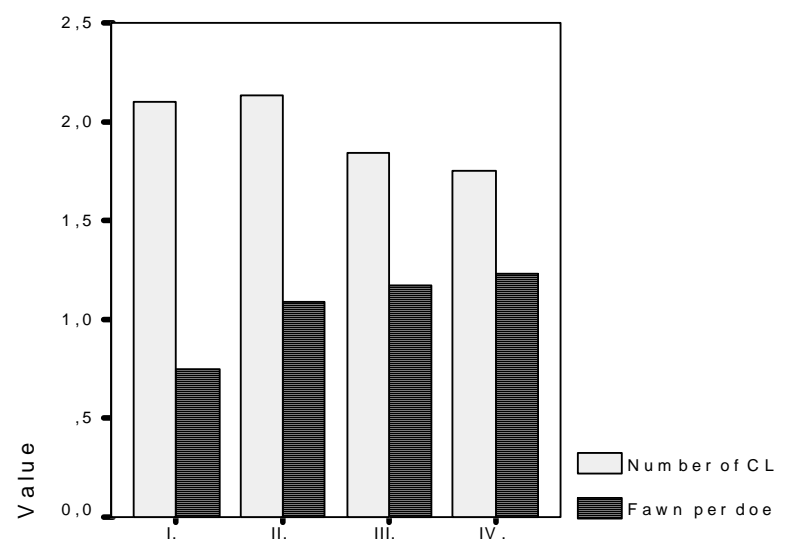

Figure 4: The average number of CL and the average BW of the does in the examined regions

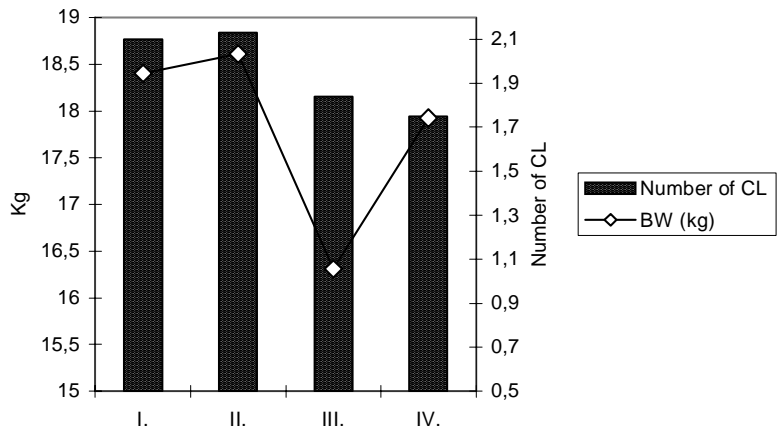

In the regions where the the ,current” (autumnwinter) condition (KFI) of the does is better, the number of offspring is usually higher (Figure 5, Table 6). This proves the roles of food supply and habitat (home range) quality in the success of breeding.

Figure 5: The raised offspring (fawn per doe) and the KFI of does in the examined regions

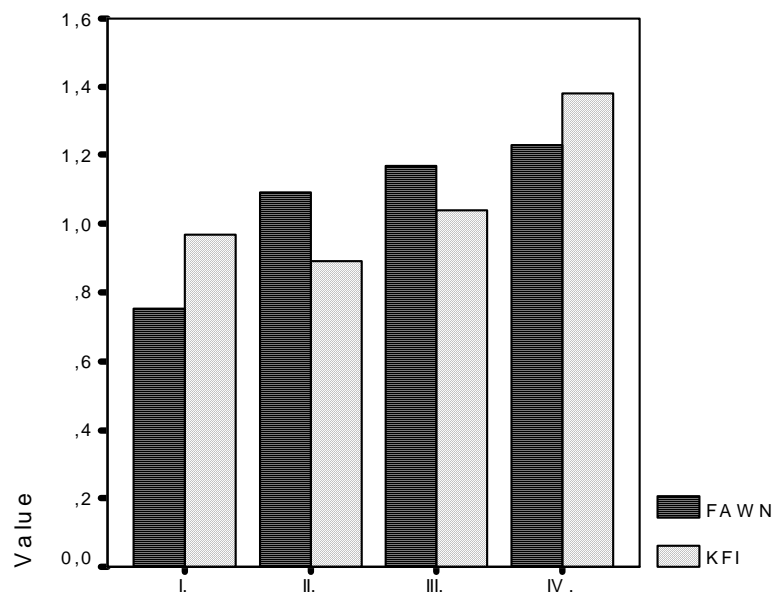

It is a proven that during the breeding period, other important environmental factors (weather, predation, poaching) also have an effect that cannot be neglected, but these are beyond the framework of this study.

\section{CONCLUSIONS}

Roe does are characteristically highly productive and are successfully fertile at a ratio of $96 \%$ (Sempéré et al., 1989), 94.4\% (Bakkay et al., 1978), 94.5\% (Fodor, 1983), 90.6\% (Sugár, 1979), 87\% (Farkas, 1985). The number of fawns (fecundity) is rather different in each stock: 2.04 fawns (Bakkay et al., 1978), 2.14 fawns (Fodor, 1983), 1.82 fawns (Farkas, 1985), 2.62 fawns (Sugár, 1979), 1.88 fawns (Kaluzinski, 1982), 1.82 fawns (Fruzinski and Labudzki, 1982 cit: Csányi, 1988), 1.92 fawns (Hewison, 1996). The number of raised offspring is just as important, in order to get to know and to control a certain stock.

In the four examined regions on the Great Hungarian Plain, the stock composition, concerning the sex ratio of the adults, is significantly different. (1:1.2-1.9). The shift of the sex ratio towards the females is a natural phenomenon with the roe, and highly influences the growth of the stock. The differences in reproductive parameters, on the one hand, reflect the differences between the regions and the quality of the stocks; on the other hand, these draw attention to the level of losses and the importance of prevention.

Despite the high number of potential offspring (CL number) - in cases where breeding losses are also high - a significant part of the offspring cannot be harvested. In the examined regions where the number of CL was high, the losses were also high and the number of raised offspring is lower. The breeding loss - in the region estimated as the best was twice as much as that of the weakest region. The environmental factors affecting the number of the offspring in a certain period limit the amount of the surviving fawns, both directly and indirectly.

According to my results, the potentially most productive does, which presumably allocated the most energy into the reproduction in the prenatal period, are at the same time the most sensitive concerning the successfulness of breeding. These does usually come from those animals with the highest $\mathrm{BW}$, as the connection between the number of potential offspring (CL number) and the average BW of the does can be revealed. Where the ratio of twin-calving does is the highest, later there were four times as many does without kids than in the highest fecundity stock. Breeding losses can be associated with the phenotype of the doe (BW, condition, age, health), but environmental factors have a crucial importance as well. There is a positive connection between the KFI of raised offspring and that of the does taken at the time of the examination. At the same time the condition of the does definitely indicates the quality of the habitat, which influences the number of raised offspring in an indirect way as well. Roe deer do not accumulate a significant amount of fat to maximalize the success of reproduction (income breeder) (Andersen et al., 2000). In this regard, the BW of the does is the most determinative (potential offspring) as well as the amount and the quality of food supply for the 
mothers and the newborn kids as well (vegetation, milk).

Furthermore, implantation takes place in the better-conditioned does sooner after reactivating of the blastocysts in diapause. Afterwards the embryo develops faster, and these fawns might reach a higher weight at birth and thus might have better chances of survival. In does with worse conditions fawns are born with lower weights and have worse survival chances because of late implantation. In the first case, milk production of the does is also better, which provides a faster post-natal development for kids (Lambert, 2000).

The direct influence of habitat is manifested in the food supply and an animal's defence against negative climatic impacts. In our research, the success of breeding was the best in the region where the number of potential offspring (CL number) was the lowest, but the amount of woods and vegetation cover was the highest. In intensively cultivated agricultural areas, where the roe deer stocks are excellent, there is abundant food in spring and in summer, the weight of the does is higher and the number of potential offspring is also higher. At the same time, the breeding losses were the highest and the number of raised offspring is the lowest in these regions. In the examined agricultural areas, the role of agro-technology in newborn fawn losses can also be considerable, but this number is unknown. These factors draw attention to the fact that the abundance of food in the vegetation period and the autumnwinter feeding is not enough in such areas. Additionally it is necessary to improve the structure of the habitat so that it will be able to provide shelter for the stock even in extreme weather conditions. This is why it is not enough to concentrate only on small game species when planning and implementing the habitat development; the needs of the roe must be considered as well.

\section{REFERENCES}

Andersen, R.-Gaillard, J. M.-Linnell, J. D. C.-Duncan, P. (2000): Factors affecting maternal care in an income breeder, the European roe deer. J. Anim. Ecol., 69. 672-682.

Bakkay, L.-Bán, I.-Fodor, T. (1978): A magyarországi őzállomány értékelése. Nimród Fórum, március, 5-9.

Caughley, G.-Sinclair, A. R. E. (1994): Wildlife ecology and management. Blackwell Science

Farkas, D. (1985): Alföldi és dunántúli őzpopulációkban végzett vemhességi vizsgálat. Nimród Fórum, június, 1-4.

Fodor, T. (1983): Az őz szaporodásbiológiája. In: Berdár, B. (szerk.): Az őz és vadászata. Mezőgazdasági Kiadó, Budapest, 63-66.

Fruzinski, B.-Labudzki, L. (1982): Demographic process in a forest roe deer population. In: Csányi, S. (szerk.): Özállományok ökológiája. Á.G.O.E. kiadványa, Budapest (1988), 57-60

Gaillard, J. M.-Boutin, J. M.-DeLorme, D.-VanLaere, G.-Duncan, P.-Lebreton, J. D. (1997): Early survival in roe deer: causes and concequences of cohort variation in two contrasted population. Oecol., 112. 4. 502-513.

Gill, R. M. A. (1994): The population dynamics of roe deer (Capreolus capreolus L.) in relation to forest habitat succession. In: Andersen, R.-Duncan, P.-Linnell, D. C. (ed.) (1998): The European Roe Deer: The Biology of Success, Scandinavian University Press, Oslo, 309-335.

Hewison, A. J. M. (1996): Variation in the fecundity of roe deer in Britain: Effects of age and body weight. Acta Theriol,
41. 2. 187-198.

Hewison, A. J. M.-Gaillard, J. M. (2001): Phenotypic quality and senescence affect different components of reproductive output in roe deer. J. Anim. Ecol., 70. 4. 600-608.

Kaluzinski, J. (1982): Dynamics and structure of a field roe deer population. Acta Theriol, 27. 385-408.

Kőnig, R. (1988): Az őzgidák és suták aránya nyáron és a korai gidaveszteségek becslése néhány magyar vadászterületen. Vadbiológia, 88. 2. 131-138.

Lambert, R. (2000): Variation in pregnancy lenght in the European Roe deer (Capreolus capreolus). Deer, 11. 8. 415-416.

Sempéré, A. J.-Renaud, G.-Bariteau, F. (1989): Embryonicdevelopment measured by ultrasonography and plasma progesterone concentrations in roe deer (Capreolus capreolus). Anim. Reprod. Sci., 20. 2. 155-164.

Strandgaard, H. (1972): An investigation of corpora lutea, embryonic development, and time of birth of roe deer (Capreolus capreolus) in Denmark. Dan. Rev. Game. Biol., 7. 6. 1-22.

Sugár, L. (1979): Erdei és mezei biotópban élő őzállományok összehasonlító vizsgálatáról. Nimród Fórum, szeptember, 1821.

Thor, G. (1995): Ecology of free-ranging roe deer population in the Swabian mountains and impact of management measures. Proceedings of the Second European Roe Deer Meeting, Munich Wildlife Society, Munich Germany 